\title{
CORRIGENDUM
}

\section{Sustained phenotypic correction in a mouse model of hypoalphalipoproteinemia with a helper-dependent adenovirus vector}

\author{
K Oka ${ }^{1,2,3}$, LM Belalcazar ${ }^{1}$, C Dieker ${ }^{1}$, EA Nour ${ }^{1}$, P Nuno-Gonzalez ${ }^{1}$, A Paul ${ }^{1}$, S Cormier ${ }^{1}$, J-K Shin ${ }^{1}$, \\ M Finegold ${ }^{4}$ and L Chan ${ }^{1,2}$
}

Gene Therapy (2007) 14, 845. doi:10.1038/sj.gt.3302952

Correction to: Gene Therapy (2007) 14, 191-202. doi:10.1038/ sj.gt.3302819

Since the above publication, the authors have noticed an error in the abbreviation of PMNs in
Table 1. The correct table and abbreviation are shown below:

Table 1 Liver pathology

\begin{tabular}{|c|c|c|c|c|c|}
\hline Baseline & & Day 3 & Day 8 & Day 15 & Day 80 \\
\hline \multirow[t]{3}{*}{$\begin{array}{l}\text { Normal or small } \\
\text { foci of lobular } \\
\text { hepatitis: } 5-6 \\
\text { mononuclear cells }\end{array}$} & PBS & $\begin{array}{l}\text { Rare tiny foci of } \\
\text { inflammation or } \\
\text { necroinflammation } \\
\text { with PMNs and } \\
\text { lymphocytes }\end{array}$ & $\begin{array}{l}\text { Rare to few foci of } \\
\text { necroinflammation }\end{array}$ & $\begin{array}{l}\text { Multiple small foci of } \\
\text { necroinflammation or one } \\
\text { small focus of hepatitis, } 1+ \\
\text { microsteatosis }\end{array}$ & $\begin{array}{l}\text { Multiple small foci of } \\
\text { necroinflammation or a } \\
\text { few foci of hepatitis }\end{array}$ \\
\hline & HDAd-AI & $\begin{array}{l}0 \text { to } 1+\text { microsteatosis, } \\
\text { slight decrease in } \\
\text { glycogen }\end{array}$ & $\begin{array}{l}\text { Rare to few foci of } \\
\text { inflammation or } \\
\text { necroinflammation }\end{array}$ & $\begin{array}{l}\text { Many tiny foci of } \\
\text { inflammation or a few foci } \\
\text { of lobular hepatitis, } \\
\text { decreased glycogen }\end{array}$ & $\begin{array}{l}\text { A few tiny or small foci } \\
\text { of hepatitis }\end{array}$ \\
\hline & FGAd-AI & $\begin{array}{l}\text { Increased mitoses, } \\
\text { slight lymphocyte } \\
\text { adherence to endo- } \\
\text { thelium, rare foci of } \\
\text { necroinflammation, } \\
\text { 1+ microsteatosis }\end{array}$ & $\begin{array}{l}\text { 4+ diffuse necrosis, } \\
\text { inflammation, and } \\
\text { hepatocellular atypia. } \\
\text { Increased mitoses }\end{array}$ & $\begin{array}{l}4+\text { severe diffuse } \\
\text { hepatocellular variation } \\
\text { and atypia, degeneration } \\
\text { necrosis, increased mitoses, } \\
\text { rare or moderate } \\
\text { inflammation }\end{array}$ & $\begin{array}{l}2+\text { necroinflammation and } \\
\text { hepatocellular variation or } \\
\text { atypia, or } 1+\text { variation in } \\
\text { hepatocellular nuclei with } \\
\text { anisocytosis, rare foci of } \\
\text { inflammation }\end{array}$ \\
\hline
\end{tabular}

Abbreviations: APOA1, apolipoprotein A-I; FGAd-AI, first-generation vector; HDAd-AI, helper-dependent vector; PBS, phosphate-buffered saline; PMNs, polymorphonuclear leukocytes; VP, vector particle.

$A P O A 1^{-1-}$ mice were treated with $4.5 \times 10^{12} \mathrm{VP} / \mathrm{kg}$ of HDAd-AI, FGAd-AI or PBS. The histopathological analysis was performed by a pathologist (MF) who was blinded to the type of treatment that the mice had received.

The authors would like to apologise for this error. 